\title{
Hepatitis $C$ virus infection acquired in childhood
}

\author{
Cristina Camarero • Natalia Ramos • Alberto Moreno • \\ Angel Asensio • Maria Luisa Mateos • Belen Roldan
}

Received: 1 November 2006 / Accepted: 6 March 2007 / Published online: 12 April 2007

(C) Springer-Verlag 2007

\begin{abstract}
Hepatitis C virus (HCV) infection occurs less frequently in children than in adult patients, and the natural history, prognosis, and clinical significance of $\mathrm{HCV}$ infection in children are poorly defined. We report here a descriptive follow-up of the clinical course, biochemical data, and viral markers observed in 37 children with antiHCV. Ten patients included in the study tested persistently negative for serum HCV-RNA (group 1) and 27 patients tested persistently positive (group 2). In group 1, serum alanine aminotransferase (ALT) was normal in all patients, while two patients had non-organ-specific autoantibodies. In group 2, serum ALT was elevated in 13 of 27 patients, and five patients had non-organ-specific autoantibodies. $\mathrm{HCV}$ genotype $1 \mathrm{a}$ and $1 \mathrm{~b}$ were the most prevalent among HCV-RNA-positive patients. Twenty liver biopsies were
\end{abstract}

C. Camarero $(\bowtie) \cdot$ N. Ramos $\cdot$ B. Roldan

Department of Pediatrics, Hospital Universitario Ramón y Cajal, Universidad de Alcalá de Henares,

Carretera de Colmenar,

28034 Madrid, Spain

e-mail: ccamarero.hrc@salud.madrid.org

\section{A. Moreno}

Department of Pathology, Hospital Universitario Ramón y Cajal, Universidad Alcalá de Henares,

Madrid, Spain

\section{A. Asensio}

Department of Preventive Medicine,

Clinica Universitaria Puerta de Hierro,

Madrid, Spain

\section{L. Mateos}

Department of Virology, Hospital Universitario Ramón y Cajal, Universidad de Alcalá de Henares,

Madrid, Spain carried out on 17 patients in our series (mean evolution time, 11.2 years; range, 3-21 years). The liver specimens showed mild necroinflammatory changes in most patients, and fibrosis was absent or low grade. Two HCV-RNApositive patients became persistently HCV-RNA negative. Of the 26 children investigated, 7 (one in group 1, six in group 2) had a co-infection with hepatitis G virus. Conclusion Most children chronically infected with HCV were asymptomatic and presented only mild biochemical evidence of hepatic injury. Autoimmunity in the form of non-organ-specific autoantibodies was common. $\mathrm{HCV}$ in children induced mild changes in the liver with a low level of fibrosis and at a low rate of progression.

Keywords Anti-liver/kidney microsomal antibody. Hepatitis C virus · Infectious hepatitis · Liver fibrosis · Nonorgan-specific autoantibodies

$\begin{array}{ll}\text { Abbreviations } \\ \text { ALT } & \text { alanine aminotransferase } \\ \text { AMA } & \text { anti-mitochondrial antibody } \\ \text { ANA } & \text { anti-nuclear antibody } \\ \text { Anti-HBc } & \text { antibodies to HBV core antigen } \\ \text { Anti-HBs } & \text { antibodies to HBV surface antigen } \\ \text { Anti-HCV } & \text { antibodies to HCV } \\ \text { Anti-HEV } & \text { antibodies to Hepatitis E virus } \\ \text { Anti-HGV } & \text { antibodies to Hepatitis G Virus } \\ \text { Anti-LKM } & \text { liver/kidney microsomal antibody } \\ \text { GPCA } & \text { gastric parietal cell antibody } \\ \text { HBV } & \text { hepatitis B virus } \\ \text { HCV } & \text { hepatitis C virus } \\ \text { HGV-RNA } & \text { hepatitis G Virus-RNA } \\ \text { HIV } & \text { human immunodeficiency virus } \\ \text { NOSAs } & \text { non-organ-specific autoantibodies } \\ \text { SMA } & \text { anti-smooth muscle antibody }\end{array}$




\section{Introduction}

$\mathrm{HCV}$ (hepatitis $\mathrm{C}$ virus) infection occurs less frequently in children than in adult patients. The natural history, prognosis and clinical significance of $\mathrm{HCV}$ infection are poorly defined in childhood [11]; in contrast, HCV infection in adults presents a high degree of chronicity, with up to $50 \%$ of all $\mathrm{HCV}$-infected adults developing progressive liver disease [21]. Results from prospective studies show that $20-30 \%$ of chronically infected adults develop compensated and eventually decompensated cirrhosis or hepatocellular carcinoma, or both, within 20 years of the initial infection [1].

The lower prevalence of HCV infection in children and the fact that most patients undergo antiviral drugs treatment result in very limited knowledge of the natural outcome of chronic HCV infection acquired at early ages of life. Thus, immediate goals in the investigation of $\mathrm{HCV}$ infection should be to characterize current epidemiology and to describe the pathogenesis and course of hepatitis $\mathrm{C}$ in children and adults [20]. To understand the evolution of $\mathrm{HCV}$ infection could be itself an important surrogate endpoint for the evaluation of infected young patients with prognostic implications and therapeutical consequences.

The aim of this study was to determine the clinical features and long-term evolution of $\mathrm{HCV}$ infection in a group of children who had never received treatment with antiviral drugs.

\section{Patients and methods}

Thirty-seven children (16 females, 21 males) with positive antibodies to hepatitis $\mathrm{C}$ (anti-HCV) were investigated retrospectively. These patients were followed-up for a period of 5 years. None had received treatment with antiviral drugs for viral hepatitis or had a history of intravenous drug abuse. All subjects made regular visits to our outpatient clinic, and the serum levels of alanine aminotransferase (ALT), albumin, prothrombin time, antinuclear antibodies (ANA), anti-mitochondrial antibodies (AMA), anti-smooth muscle antibodies (SMA), liverkidney anti-microsomal antibodies type I (LKM), antigastric parietal cells antibodies (GPCA), rheumatoid factor, thyroxine (T4), thyroid stimulating hormone (TSH), antithyroid antibodies, anti-HCV and HCV-RNA were determined at least on five consecutive occasions at 1-year intervals. Hepatitis B virus (HBV) surface antigen (HBsAg), antibodies to HBV surface antigen (anti-HBs), antibodies to HBV core antigen (Anti-HBc), human immunodeficiency virus (HIV) and antibodies to hepatitis $\mathrm{E}$ (anti-HEV) were investigated in all patients during one visit. Hepatitis G virus-RNA (HGV-RNA) and antibodies to
HGV (anti-HGV) were determined in 26 patients. Genotypes of $\mathrm{HCV}$ were performed in 21 viremic children.

The duration of infection was calculated as the interval between the presumed date of infection and the date of the last visit to the clinic. Liver biopsies were obtained in 17 patients. Repeated biopsies were performed in three patients.

Viral markers for HBV, HCV and HIV were tested by third generation ELISA (Axsym; Abbott Diagnostics, Chicago, Ill.). Anti-HEV was detected by a commercially available ELISA (Bioelisa HEV IgG; Biokit, Barcelona, Spain). HGV-RNA and anti-HEV antibodies were detected using commercial tests (Roche Diagnostics, Mannheim, Germany). HCV-RNA was detected by PCR (Amplicor HCV PCR test, Roche Diagnostics), and HCV genotyping was performed by a second generation line probe assay (INNO-LIPA HCV; Innogenetics, Ghent, Belgium).

Liver biopsies were performed percutaneously and under the ultrasound guidance of an experienced operator. All liver biopsy specimens (>12 mm long) were fixed in formalin, embedded in paraffin stained with hematoxylin-eosin and Masson's trichrome and then observed by a single experienced pathologist (AM). Histological necroinflammatory activity and fibrosis were scored separately. The degree of histological necrosis with inflammatory activity was scored using the three parameters of the histological activity index (HAI) developed by Knodell et al. [12]; these consist of: (1) piecemeal necrosis and bridging necrosis (score: 0-10), (2) lobular cytolysis (score: 0-4) and (3) portal inflammation (score: 0-4). Fibrosis was scored independently using the following system: F0, absence of fibrosis; F1, fibrous expansion of portal areas; F2, portal to portal bridging fibrous tracts; F3, portal-central bridging fibrous septa; F4, cirrhosis (bridging fibrous septa with parenchymal nodules). This score is a modification of the fibrosis scoring system of Knodell's method and introduces one additional degree of fibrosis. Macrovesicular steatosis was graded semiquantitatively using a modified score from Brunt et al. [5]. Alternative and additional diagnoses identified in the liver biopsy were also recorded.

\section{Results}

Mean chronological age for the 37 patients (21 males and 16 females) at the last follow-up evaluation was 20.1 years (range: 9-30 years). Most of the subjects were diagnosed among patients who were screened for HCV infection after receiving transfusions of blood products for heart surgery, hematological diseases or casual injuries before 1992. Thus, most of the patients included in the study presented with other diseases that were unrelated to $\mathrm{HCV}$ infection: 16 patients had a congenital heart disease, seven had various hematological disorders, three had neurological diseases, 
Table 1 Characteristics and biologic data of children with $\mathrm{HCV}$ infection

\begin{tabular}{|c|c|c|c|}
\hline & $\begin{array}{l}\text { Patients } \\
\text { negative for } \\
\text { HCV-RNA } \\
(n=10)\end{array}$ & \multicolumn{2}{|c|}{$\begin{array}{l}\text { Patients } \\
\text { positive for } \\
\text { HCV-RNA } \\
(n=27)\end{array}$} \\
\hline Age (years) at the follow-up evaluation ${ }^{\mathrm{a}}$ & $18(9-26)$ & \multicolumn{2}{|c|}{$20(9-30)$} \\
\hline $\begin{array}{l}\text { Duration of the HCV infection (years) in } \\
36 \text { patients at the follow-up evaluation }\end{array}$ & $14(6-23)$ & \multicolumn{2}{|c|}{$16(5-30)$} \\
\hline \multicolumn{4}{|l|}{ Route of infection } \\
\hline Parenteral & 10 & \multicolumn{2}{|l|}{24} \\
\hline Vertical & 0 & \multicolumn{2}{|l|}{2} \\
\hline Unknown & 0 & \multicolumn{2}{|l|}{1} \\
\hline Alanine aminotransferase $(\mathrm{U} / \mathrm{l})$ & & $\begin{array}{c}\text { First } \\
\text { visit }\end{array}$ & $\begin{array}{c}\text { Last } \\
\text { visit }\end{array}$ \\
\hline Normal $(n)$ & 10 & 7 & 14 \\
\hline$\leq 2 \times \operatorname{UNL}(n)^{\mathrm{b}}$ & 0 & 6 & 7 \\
\hline $2-4 \times \operatorname{UNL}(n)$ & 0 & 5 & 5 \\
\hline$>4 \times \operatorname{UNL}(n)$ & 0 & 9 & 1 \\
\hline \multicolumn{4}{|l|}{ Non-organ specific antibodies } \\
\hline Antinuclear antibody & 0 & \multicolumn{2}{|l|}{2} \\
\hline Anti-mitochondrial antibodies & 1 & \multicolumn{2}{|l|}{0} \\
\hline Anti-smooth muscle antibodies & 0 & \multicolumn{2}{|l|}{1} \\
\hline $\begin{array}{l}\text { Liver-kidney anti-microsomal antibody } \\
\text { type } 1\end{array}$ & 1 & \multicolumn{2}{|l|}{1} \\
\hline Gastric parietal cell antibodies & 0 & \multicolumn{2}{|l|}{1} \\
\hline \multicolumn{4}{|l|}{ HCV genotype } \\
\hline $1 \mathrm{a}$ & & \multicolumn{2}{|l|}{8} \\
\hline $1 \mathrm{~b}$ & & \multicolumn{2}{|l|}{12} \\
\hline $2 \mathrm{a}$ & & \multicolumn{2}{|l|}{1} \\
\hline Unknown & & \multicolumn{2}{|l|}{6} \\
\hline $\mathrm{HBV}$ & 0 & \multicolumn{2}{|l|}{0} \\
\hline HIV & 1 & \multicolumn{2}{|l|}{0} \\
\hline HGV-RNA/Anti-HGV $(n=26)$ & $1 / 0$ & \multicolumn{2}{|l|}{$4 / 2$} \\
\hline Anti-HEV & 0 & \multicolumn{2}{|l|}{0} \\
\hline
\end{tabular}

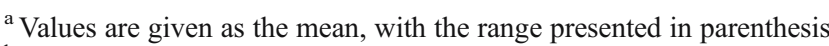
${ }^{\mathrm{b}}$ UNL, Upper normal level

one had vesicoureteral reflux and one had Turner syndrome associated to IgA deficiency.

Ten patients were anti-HCV-positive and HCV-RNAnegative (Group 1). The presence of HCV-RNA was demonstrated in the other 27 patients (Group 2). Demographic characteristics and the main results obtained in these children are shown in Table 1.

\section{Group 1}

The once-yearly PCR analysis revealed that ten patients had positive anti-HCV and negative viremia, which reflected an ongoing or past infection with HCV. These patients were asymptomatic, and the liver function tests remained normal in all but two who had been diagnosed with congestive heart failure; the liver abnormalities of these two patients were normalized after their cardiac condition had improved.
One female patient presented persistent positive AMA for 3 years, which then normalized and remained negative during the subsequent 9-year follow-up period. Throughout this period the patient was asymptomatic, and liver tests were normal. Two years after the laboratory tests were negative for antibodies, the patient presented with psoriasis. Another patient had persistent high titers (1:620) of antiLKM. Fifteen years after acquiring the infection this patient lost the anti-HCV but the anti-LKM remained positive for two more years. During the follow-up this patient did not present liver abnormalities or other diseases.

During the follow-up span of this study, another female patient became persistently anti-HCV negative 12 years after she was infected. At the time of writing, eight patients remain anti-HCV-positive and HCV-RNA-negative, and they show no evidence of liver disorders.

\section{Group 2}

HCV-RNA was detectable in the blood of 27 patients, two of whom became HCV-RNA-negative. The age of exposure to the infection and the type of exposure could not be established in one patient; following the detection of $\mathrm{HCV}$ in the blood serum, this patient was followed for 11 years and was positive for HCV up to and including the last follow-up visit.

All patients, with one exception, were asymptomatic. The exception had been diagnosed with leukemia in 1987 and received transfusions of blood products on several occasions. She underwent chemotherapy and had a cholestatic hepatitis; liver tests revealed persistent abnormalities. Anti-HCV and HCV-RNA were detected in 1991. The patient presented portal hypertension and progressive liver failure, and when she was 8 years old, in 1993, she received a liver transplant.

The evolution of serum ALT levels is shown in Table 1. Serum levels of albumin and prothrombin time were abnormal only in the patient who developed hepatic failure.

The presence of non-organ-specific autoantibodies (NOSAs) was detected in five patients. One patient (genotype1a) diagnosed with a single ventricle and Fontan surgery developed persistent anti-LKM (titers 1:160-1:620) and the rheumatoid factor throughout the evolution of the disease. Liver biopsy could not be obtained in this patient. Another male patient (genotype 1b) had positive ANA for 2 years, which subsequently normalized. This patient had increased ALT, and the liver biopsy showed minimal necrosis with inflammatory changes (HAI: 2) and no fibrosis. A third patient (genotype 1b) had persistent PGCA during her follow-up period (10 years), with slightly elevated ALT levels, mild necrosis with inflammatory changes (HAI: 4) and minimal fibrosis (stage 1). A fourth patient (genotype1b) with AST levels greater than fourfold the upper normal level presented SMA during the last 2 years of her follow-up (HAI: 6). The patient diagnosed 
Table 2 Histopathological features of patients positive for HCV-RNA
Liver biopsy

Patients

(n)

\begin{tabular}{ll}
\hline $\begin{array}{l}\text { Necroinflammatory } \\
\text { activity }\end{array}$ \\
$1-2$ & 6 \\
$3-4$ & 7 \\
$5-6$ & 4 \\
$6-18$ & 0 \\
Fibrosis & \\
F0 & 8 \\
F1 & 6 \\
F2 & 2 \\
F3 & 0 \\
F4 (Cirrhosis) & 1 \\
Steatosis & 0 \\
\end{tabular}

with Turner syndrome and IgA deficiency (genotype 1b) developed throughout the years a seronegative poli-articular rheumatoid arthritis, psoriasis and celiac disease. She had intermittently positive ANA.

The levels of T4 and TSH were normal in all patients, and no patient developed antithyroid antibodies.

Abdominal ultrasounds did not show significant abnormalities. Only the patient who presented cirrhosis had changes associated to portal hypertension.

Liver biopsies were performed in viremic patients who presented altered hepatic function tests and for whom parental consent had been obtained. Seventeen patients underwent 20 liver biopsies. Mean evolution time of the infection at the time of biopsy was established in 16 patients (mean: 11.2 years; range: 3-21 years). The results on necroinflammatory activity and fibrosis are shown in Table 2 .

A second hepatic biopsy was performed in three patients after 5, 12 and 14 years, respectively. The minimal necroinflammatory activity observed in the first biopsy specimens of these three children remained unchanged in the second biopsy. One of the patients progressed from F0 to F1 fibrosis. A second patient never presented with fibrosis, and both samples of the third patient had minimal fibrosis (F1).
During the follow-up period, $2 / 27$ patients became persistently HCV-RNA-negative (for 9 and 10 years, respectively). Both patients showed minimal necrosis and inflammatory activity with minimal fibrosis (F1) in the biopsy performed before HCV-RNA clearance. One patient of Group 1 was HIV-positive, while one patient of Group 1 and six patients of Group 2 were HGV-positive.

Viral coinfections observed in both groups are expressed in Table 1.

\section{Discussion}

In this study, chronic hepatitis $\mathrm{C}$ infection was silent in most of the children, and there was little biochemical evidence of liver disease in these patients. Only one girl with portal hypertension and liver failure developed symptoms related to the infection. Consequently, our data suggest that $\mathrm{HCV}$ infection may be currently underdiagnosed in children and, moreover, that young patients could become a potential source of infection. We therefore strongly recommend that children falling in risk groups be screened for HCV infection.

Of the 37 pediatric patients in this series, seven (19\%) had NOSAs. These antibodies are highly prevalent in subjects exposed to the $\mathrm{HCV}$, and a positive test result for SMA, GPCA and ANA is part of the natural course of chronic HCV infection in adults and children [7]. Lenzi et al. [13] reported a higher prevalence of NOSAs in antiHCV-positive adult patients than in normal controls ( 25 vs. $6 \%$ ). Stroffolini et al. [22] found positive NOSAs in 36.9\% of 502 subjects with HCV-RNA-positive chronic hepatitis. Muratori et al. [16] detected positive NOSAs in 16 of 47 children (34\%) with chronic hepatitis C, and anti-LKM was present in $11 \%$ of the children.

Of the 37 children participating in our study who manifested past or active HCV infection, two had serum antiLKM. This incidence is lower than that observed by Muratori et al. (11\%) [16] and Bortolotti et al. (10.3\%) [4] in children

Table 3 Hepatic fibrosis in biopsies from children with HCV infection

\begin{tabular}{|c|c|c|c|c|c|c|}
\hline & $\begin{array}{l}\text { Vogt } \\
\text { et al. [23] }\end{array}$ & $\begin{array}{l}\text { Hoshiyama } \\
\text { et al. [9] }\end{array}$ & & $\begin{array}{l}\text { Guido } \\
\text { et al. [8] }\end{array}$ & $\begin{array}{l}\text { El-Raziky } \\
\text { et al. [6] }\end{array}$ & This report \\
\hline Number of patients & 17 & 38 & & 112 & $26^{\mathrm{a}}$ & 17 \\
\hline $\begin{array}{l}\text { Mean duration of the HCV infection (year) } \\
\text { Fibrosis }\end{array}$ & $21.2 \pm 4.6$ & $7.1 \pm 2.8(n=23)$ & $12.9 \pm 3.1(n=15)$ & $8.04 \pm 5.3$ & Non-determined & $11.2 \pm 5,6$ \\
\hline No/low grade & $14 / 2^{\mathrm{b}}$ & 23 & 15 & $25 / 81$ & $20 / 4$ & $7 / 9$ \\
\hline Severe/cirrhosis & $0 / 1^{\mathrm{c}}$ & 0 & 0 & $5 / 1$ & $1 / 1^{\mathrm{d}}$ & $0 / 1^{\mathrm{e}}$ \\
\hline
\end{tabular}

${ }^{a}$ Some patients were co-infected with HBV and /or had secondary iron overload

${ }^{\mathrm{b}}$ Two patients with congestive heart failure

${ }^{\mathrm{c}}$ Patient with Anti-HBs, anti-HBc and anti-HEV antibodies

${ }^{\mathrm{d}}$ This 12-year-old cirrhotic patient was not thalassaemic and HBV markers were negative

${ }^{\mathrm{e}}$ This leukemic patient was infected with $\mathrm{HCV}$ and was also receiving chemotherapy concurrently 
with $\mathrm{HCV}$ infection. A possible explanation for this finding is the higher age and longer mean duration of HCV infection in the patients included in our series in comparison to the children in the other two studies. The prevalence reported by Lenzi et al. (1.3\% [13]), Stroffolini et al. (2.25\% [22]) and Reddy et al. (0\% [18]) in adults support this hypothesis. AntiLKM is an immunomarker of type 2 autoimmune hepatitis [2] that tends to present at younger ages and to affect mainly children. Our data suggest that age may be a factor contributing to the presence of anti-LKM1 in children infected with HCV. Moreover, we observed that one of our non-viremic patients had persistent antibodies after the test for anti-HCV became negative.

Liver specimens from the children with hepatitis $\mathrm{C}$ showed mild necroinflammatory changes and a low level of fibrosis. In most patients, fibrosis was absent or low grade. Only one patient, as mentioned above, developed cirrhosis and liver failure over a period of 6 years. This leukemic patient had other additional risk factors for liver damage that may have affected this outcome. In this respect, Hoshiyama et al. [9] observed that chronic hepatitis $\mathrm{C}$ is more frequent among children with hepatitis $\mathrm{C}$ infection following blood transfusions for malignant disease than in patients with hepatitis $\mathrm{C}$ following blood transfusions for open heart surgery.

We have compared our results with those obtained from other pediatric series $[6,8,9,23]$. Table 3 summarizes the data on fibrosis obtained from liver biopsies of 210 pediatric patients (above-mentioned studies). Fibrosis was not detected or was low grade in 200 patients (95\%), and severe fibrosis or cirrhosis was detected in ten patients (5\%). Minola et al. [15] and Poynard et al. [17] demonstrated an inverse correlation between age at HCV infection and progression to cirrhosis that suggests that chronic HCV infection in childhood induces mild changes in the liver with a low level of fibrosis and a low rate of progression. However, it has been observed that mild chronic hepatitis $\mathrm{C}$ can be a progressive disease in adult patients [3,19] and that the long evolution of infection acquired in childhood could increase the risk of fibrosis. Thus, some children infected early in life, in whom chronic disease has a mild liver expression, might develop fibrosis in adulthood.

It is noteworthy that $6 / 27$ of the children with $\mathrm{HCV}$ infection in our series had a co-infection with HGV (HGVRNA-positive) or had a past $\mathrm{HGV}$ infection (antiHGV-positive). This prevalence of HGV infection is higher than that found in healthy children (6\%) in Spain [10]. These data suggest that HCV-infected children must be considered to be a risk group for $\mathrm{HGV}$ infection since $\mathrm{HCV}$ and $\mathrm{HGV}$ are both parenterally transmitted. Moreover, no differences were observed in biochemical and histological findings in $\mathrm{HCV}$-infected children with and without a concomitant infection with $\mathrm{HGV}$, which suggests that superimposed HGV infection does not influence the course of $\mathrm{HCV}$ infection.

Conversely, our data do not support that HEV, which can be transmitted by a parenteral route [24], is prevalent in children who had undergone blood transfusions (prevalence rate: $0 \%$ ). However, this low value may result from the low prevalence of HEV infection in Spain (2.8\%) [14].

\section{Conclusion}

Most children chronically infected with HCV are asymptomatic and present only mild biochemical evidence of hepatic injury. Spontaneous clearing of the virus occurs occasionally. Autoantibodies are common in HCV patients. The natural history of chronic hepatitis $\mathrm{C}$ in children differs from that in adults since $\mathrm{HCV}$ infection is relatively benign, induces mild changes in the liver with a low level of fibrosis and a low rate of progression and is rarely associated with severe or decompensate liver disease.

\section{References}

1. Afdhal NH (2004) The natural history of hepatitis C. Semin Liver Dis 24[Suppl 2]:3-8

2. Alvarez F, Berg PA, Bianchi FB, Bianchi L, Burroughs AK, Cancado EL, Chapman RW, Cooksley WGE, Czaja AJ, Desmet VJ, Donaldson PT, Eddleston ALWF, Fainboim L, Heathcote J, Homberg JC, Hoofnagle JH, Kakumu S, Krawitt EL, Mackay IR, MacSween RNM, Maddrey WC, Manns MP, McFarlane IG, Meyer zum Büschenfelde KH, Mieli-Vergani G, Nakanuma Y, Nishioka M, Penner E, Porta G, Portmann BC, Reed WD, Rodes J, Schalm SW, Scheuer PJ, Schrumpf E, Seki T, Toda G, Tsuji T, Tygstrup N, Vergani D, Zeniya M (1999) International autoimmune hepatitis group report: review of criteria for diagnosis of autoimmune hepatitis. J Hepatol 31:929-938

3. Boccato S, Pistis R, Noventa F, Guido M, Benvegnu L, Alberti A (2006) Fibrosis progression in initially mild chronic hepatitis C. J Viral Hepat 13:297-302

4. Bortolotti F, Muratori L, Jara P, Hierro L, Verucchi G, Giacchino R, Barbera C, Zancan L, Guido M, Resti M, Pedditzi S, Bianchi F, Gatta A (2003) Hepatitis C virus infection associated with liverkidney microsomal antibody type 1 (LKM1) autoantibodies in children. J Pediatr 142:185-190

5. Brunt EM, Janney CG, DiBisceglie AM, Neuschwander-Tetri BA, Bacon BR (1999) Nonalcoholic steatohepatitis: a proposal for grading and staging the histological lesions. Am J Gastroenterol 24:2467-2474

6. El-Raziky MS, El-Hawary M, El-Koofy N, Okasha S, Kotb M, Salama K, Esmat G, El-Raziky M, Abouzied AM, El-Karaksy H (2004) Hepatitis C virus infection in Egyptian children: single centre experience. J Viral Hepat 11:471-476

7. Gregorio GV, Pensati P, Iorio R, Vegnente A, Mieli-Vergani G, Vergani D (1998) Autoantibody prevalence in children with liver disease due to chronic hepatitis $\mathrm{C}$ virus (HCV) infection. Clin Exp Immunol 112:471-476

8. Guido M, Bortolotti F, Leandro G, Jara P, Hierro L, Larrauri J, Barbera C, Giacchino R, Zancan L, Balli F, Crivellaro C, Cristina 
E, Pucci A, Rugge M (2003) Fibrosis in chronic hepatitis C acquired in infancy: is it only a matter of time? Am J Gastroenterol 98:660-663

9. Hoshiyama A, Kimura A, Fujisawa T, Kage M, Kato H (2000) Clinical and histologic features of chronic hepatitis $\mathrm{C}$ virus infection after blood transfusion in Japanese children. Pediatrics 105:62-65

10. Infante D, Pich M, Tormo R, Sauleda S, Montane C, Esteban JL, Esteban R (2000) Prevalence of hepatitis G virus in healthy children in liver disease and human immunodeficiency virus-1 infection: response to interferon. J Pediatr Gastroenterol Nutr 30:385-390

11. Kelly D, Skidmore S (2002) Hepatitis C-Z: recent advances. Arch Dis Child 86:339-343

12. Knodell RG, Ishak KG, Black WC, Chen TS, Craig R, Kaplowitz N, Kiernan TW, Wollman J (1981) Formulation and application of a numerical scoring system for assessing histological Biopsy procedure and histological evaluation activity in asymptomatic chronic active hepatitis. Hepatology 1:431-445

13. Lenzi M, Bellentani S, Saccoccio G, Muratori P, Masutti F, Muratori L, Cassani F, Bianchi FB, Tiribelli C (1999) Prevalence of non-organ-specific autoantibodies and chronic liver disease in the general population: a nested case-control study of the Dionysos cohort. Gut 45:435-441

14. Mateos ML, Camarero C, Lasa E, Teruel JL, Mir N, Baquero F (1998) Hepatitis E virus: relevance in blood donors and other risk groups. Vox Sang 75:267-269

15. Minola E, Prati D, Suter F, Maggiolo F, Caprioli F, Sonzogni A, Fraquelli M, Paggi S, Conte D (2002) Age at infection affects the long-term outcome of transfusion-associated chronic hepatitis C. Blood 99:4588-4591

16. Muratori P, Muratori L, Verucchi G, Attard L, Bianchi FB, Lenzi M (2003) Non-organ-specific autoantibodies in children with chronic hepatitis $\mathrm{C}$ : clinical significance and impact on interferon treatment. Clin Infect Dis 37:1320-1326

17. Poynard T, Ratziu V, Charlotte F, Goodman Z, McHutchinson J, Albrecht J (2001) Rates and risk factors of liver fibrosis progression in patients with chronic hepatitis C. J Hepatol 34:730-739

18. Reddy KR, Krawitt EL, Homberg JC, Jeffers LJ, Demedina M, Chastenay B, Poupon R, Opolon P, Beaugrand M, Abuaf N, Gregeois J, Johanet C, Schiff ER (1995) Absence of anti-LKM-1 antibody in hepatitis $\mathrm{C}$ viral infection in the United States of America. J Viral Hepat 2:175-179

19. Ryder SD, Irving WL, Jones DA, Neal KR, Underwood JC; Trent Hepatitis C Study Group (2004) Progression of hepatic fibrosis in patients with hepatitis $\mathrm{C}$ : a prospective repeat liver biopsy study. Gut 53:451-455

20. Schwarz KB, Balistreri W (2002) Viral Hepatitis. J Pediatr Gastroenterol Nutr 35 Suppl 1:S29-S32

21. Seeff LB (2002) Natural history of chronic hepatitis C. Hepatology 36[5 Suppl 1]:S35-S46

22. Stroffolini T, Colloredo G, Gaeta GB, Sonzogni A, Angeletti S, Marignani M, Pasquale G, Venezia G, Craxi A, Almasio P (2004) Does an "autoimmune" profile affect the clinical profile of chronic hepatitis C? An Italian multicentre survey. J Viral Hepat 11:257-262

23. Vogt M, Lang T, Frosner G, Klingler C, Sendl AF, Zeller A, Wiebecke B, Langer B, Meisner H, Hess J (1999) Prevalence and clinical outcome of hepatitis $\mathrm{C}$ infection in children who underwent cardiac surgery before the implementation of blooddonor screening. N Engl J Med 341:866-870

24. Xia NS, Zhang Zheng YJ, Ge SX, Ye XZ, Ou SH (2004) Transfusion of plasma from a blood donor induced hepatitis $\mathrm{E}$ in Rhesus monkey. Vox Sang 86:45-47 